\title{
Innovativeness in Science Education: An Examination of Secondary School Students' Perceptions
}

\author{
Bahar Muradoğlu ${ }^{1}$, Nevzat Yiğit ${ }^{1}$, Ebru Mazlum Güven ${ }^{1 *}$ \\ ${ }^{1}$ Department of Mathematics and Science Education, Trabzon University, Turkey \\ *Corresponding author: eumazlum@gmail.com
}

\begin{abstract}
As innovation has gained importance worldwide, educating students as individuals with innovative qualities has become imperative. Therefore, identifying students' perceptions of innovativeness in science lessons has become an issue of concern. The aim of this study was to determine secondary school students' perceptions of innovativeness. The research was conducted according to the survey method. 'Perceptions of Innovative Thinking Scale,' was revised, and necessary scale development steps were followed. Accordingly, secondary school students' general innovative thinking perceptions and the relationships of the scale subdimensions with the variables were determined with single and correlational survey models. After the responses that 831 students gave to the scale were analysed, it was determined that the students' perceptions of innovativeness were high and that gender excepted, grade level, achievement in the subject of science, participation in the TÜBİTAK 4006 science fair, and the case of receiving programming training created significant differences in the subdimensions. The research findings were discussed according to the literature. It was recommended that STEM and programming be included in science courses and that teachers guide these processes.
\end{abstract}

Keywords Science Education, Innovativeness in Science Education, Perceptions of Innovativeness

\section{INTRODUCTION}

As the world's resources decrease, countries' ability to innovate to gain an advantage in a competitive environment and their labor force increases indicates that adopting innovations is important (Yllmaz-Öztürk, 2015). Therefore, training individuals who possess innovative qualities have also become state policy (Açıkgöz-Ersoy \& Muter-Şengül, 2008; Öğüt, Aygen, \& Demirsel, 2007). Innovativeness, which is defined as 'the state of being open to innovations,' is the ability to take risks, renew oneself, use new technologies, produce new ideas, cooperate, think creatively, and contribute to the change or development of existing situations (Demirel \& Seçkin, 2008). Besides keeping pace with changes by using innovations, individuals themselves must also be able to contribute to the changes (Kılıçer \& Odabaş1, 2010).

With the constant drive for innovation in the world's economy and the increasing demand for graduating students who are more innovative contributors to society, interest in defining and measuring individual innovativeness is growing (Menold, Jablokow, Purzer, Ferguson, \& Ohland, 2014; Yenice \& Alpak Tunç, 2019; Weis, Scharf, \& Gryl, 2017). Accordingly, teaching programs must be prepared in such a way as to serve to educate individuals who can investigate, inquire, solve the problems they encounter, and benefit themselves and society; in short, who are qualified to respond to the needs of contemporary society (Menold et al., 2014). For this purpose, it is seen that to keep up in the innovation race, the subject of 'Engineering and Design Skills' was added to the 2018 Turkish Science Curriculum. These skills allow students to examine problems from an interdisciplinary perspective, attain a level at which they can invent and innovate, and create products by using the knowledge and skills they have acquired (MoNE, 2018). Therefore it is considered the most important means for students to acquire perceptions towards innovative thinking first, and later innovativeness itself.

It is expected that individuals be open to innovations, adopt innovations, and closely follow developments in technology. Moreover, individuals differ in terms of adopting innovations, and it is seen that they are separated into five categories, namely innovative, traditionalist,

\footnotetext{
Received: 15 April 2021

Revised: 23 September 2021

Published: 1 March 2022
} 
pioneering, inquiring, and sceptical (Rogers, 1995). It is also known that individuals' socioeconomic levels and different demographic characteristics influence their adoption of innovations (Daghfous, Petrof, \& Pons, 1999).

In the literature, although in some studies it was expected that creativity, which is stated to be closely related to innovativeness, would not differ according to gender (Baysal, Kaya, \& Üçüncü, 2013; Midilli, 2019; Polat, 2017; Ulusoy-Yılmaz \& Yıldız, 2019). In other studies, it is seen that a difference was revealed in favor of women (Barış1k, 2019; Gök \& Erdoğan, 2011; Rıza, 1999). Studies conducted concerning innovativeness determined that total mean scores increased from $6^{\text {th }}$ grade to $8^{\text {th }}$ grade. Moreover, it was revealed that $5^{\text {th }}$-grade students' total means innovativeness scores were higher than $6^{6^{\text {th }}}$-grade students' scores (Deveci \& Kavak, 2020). It is known that students who are high achievers in science also have high levels of creativity (Kılıç \& Tezel, 2012) and that students with high general academic achievement also have high levels of innovativeness (Deveci \& Kavak, 2020). When considering students' creativity scores, differences were determined between students with high end-of-term grades in science and those with low grades, favoring those with high achievement (Kılıç \& Tezel, 2012). Regarding innovativeness, differences were determined between students with high academic achievement and those with low achievement in favor of the high achievers (Deveci \& Kavak, 2020). It is known that states of participation in the project preparation process, which allows students to acquire several skills and to develop these skills, enables their creativity to develop positively and allows them to generate new ideas (Atalmış, Selçuk, \& Ataç, 2018; Seechaliao, 2017; Siew \& Ambo, 2018). Furthermore, it has been determined that giving students the chance to develop their creativity and the ability to produce innovations has benefits such as gaining self-confidence and learning to cooperate (Avc1, Su-Özenir, \& Yücel, 2016) and that at the end of the process, students present different project ideas (Soyuçok, 2018). In programming, which is one of the skills expected from students in the $21^{\text {st }}$ century, students can solve problems by figuring them out and using their creativity. At this point, it is stated that in students who learn programming, the development of their problem solving, logical reasoning, creativity, and innovativeness will also be affected positively (Aytekin, Çakır, Yücel, \& Kulaözü, 2018; Yoon, 2018). By this means, in programming, students will have the opportunity to put their ideas into practice by thinking creatively and innovatively. They will also be able to develop their innovativeness in a technological sense.

Literature indicates that many factors can influence students' innovative thinking as mentioned above. Educational policies and schools need to create learning environments to foster innovative thinking. Therefore, this contribution seeks to give insight into kinds of innovative thinkers and provide teachers to evaluate students' perception of innovativeness levels, and enable them to improve their teaching to promote students' innovativeness. By revealing which variables affect students' perceptions of innovative thinking and to what extent, it will be possible to offer students innovative thinking and learning environments.

\subsection{Aim and Importance of the Study}

Considering the literature, it can be thought that secondary school students' gender, grade level, success grades in the subject of science, project preparation process, and programming training may influence their perceptions of innovative thinking. Consequently, it is necessary to determine students' perceptions of innovativeness and the variables that positively affect them.

It has been seen that innovativeness studies gained importance worldwide. It is stated that students at all stages of education students need to possess this skill, and measures are taken for this purpose. As the concept of innovativeness has gained so much importance and it is also clearly stated in the Science Curriculum in Turkey (MoNE, 2018), the position of students attending secondary schools has become an issue of concern. Accordingly, the fact that there are an inadequate number of studies at the secondary school level in the literature is regarded as a deficiency. When the literature is examined, the limited number of studies, and the fact that they have generally been conducted on innovativeness in teachers, preservice teachers, school administrators, and academicians in different branches, is striking (Aldahdouh, Nokelainen, \& Korhonen, 2020; Atamanova \& Bogomaz, 2021; Bayrakçı \& Eraslan, 2014; Demir-Başaran \& Keleş, 2015; Kasapoğlu, 2018; Kinay \& Suer, 2020; Sar1 \& Kartal, 2018; Webster et al., 2020). It is striking that studies related to innovativeness mainly collect around teachers and in higher education (Bautista, 2021; Mikhailova, 2019; Kinay \& Suer, 2020; Nguyen, Pietsch, \& Gümüş, 2021; Öztürk, Önder, \& Güven-Yıldırım, 2019; Parlar, Polatcan, \& Cansoy, 2019; Polat, 2017). Almost no studies have been conducted about secondary school students' innovativeness (Akkaya, 2016; Deveci \& Kavak, 2020; Kavac1k, Yanpar-Yelken, \& Sürmeli, 2015;). Among these studies, very few have been carried out on perceptions of innovative thinking, while in one study conducted according to a mixed method (Deveci \& Kavak, 2020), students' general innovativeness was examined. Therefore, this study in which secondary school students' innovativeness is examined is thought to contribute to the science education. The current study differs from studies in the literature in that it examines the effect of different variables on students' perceptions of innovative thinking based on subfactors and includes a detailed research process for revealing the existing state of their innovativeness. Moreover, it is considered that the study 
will serve as a guide for other researchers who will research in the field of science education.

This study attempts to determine secondary school students' perceptions of innovativeness. In line with this primary aim, the study's research questions are as follows.

1. What is the level of secondary school students' perceptions of innovativeness?
2. Is there any differences between the secondary school students' 'Innovator,' 'Traditionalist,' and 'Open to Inquiry' scores according to their gender?

3. Is there any differences between the secondary school students' 'Innovator,' 'Traditionalist,' and 'Open to Inquiry' scores according to grade level?

4. Is there any differences between the secondary school students' 'Innovator,' 'Traditionalist,' and 'Open to Inquiry' scores according to success in science?

Table 1 Distribution of demographic characteristics of secondary school students

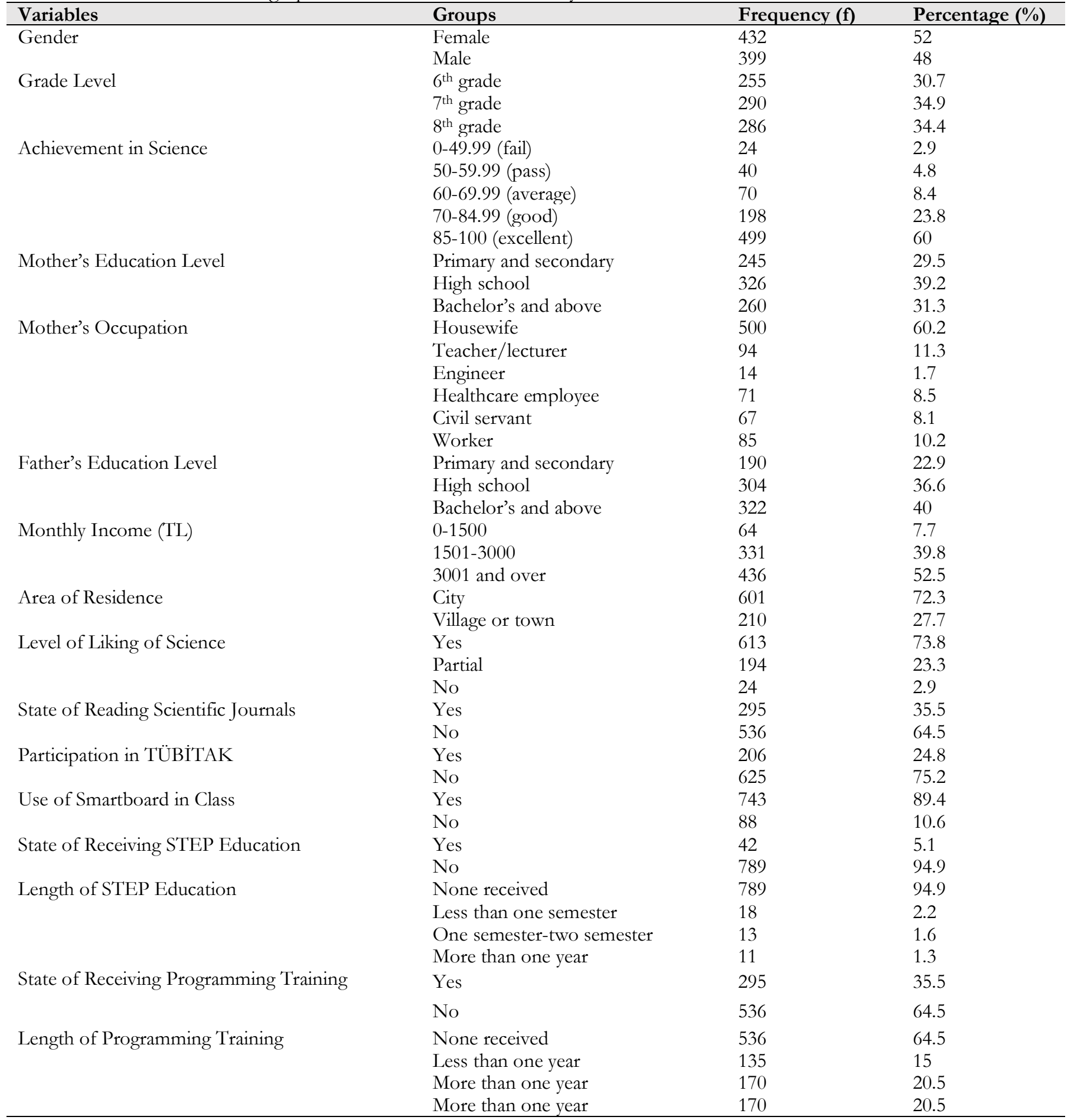


5. Is there any difference between the secondary school students' 'Innovator,' 'Traditionalist,' and 'Open to Inquiry' scores according to participation in the TÜBİTAK (The Scientific and Technological Research Council of Turkey)?

6. Is there any differences between the secondary school students' 'Innovator,' 'Traditionalist,' and 'Open to Inquiry' scores according to receiving programming training?

\section{METHOD}

\subsection{Research Model}

In this study survey method was applied to determine students' perceptions of innovativeness. Quantitative data were collected to reveal secondary school students' perceptions of innovative thinking and the relationship with different variables. By determining the secondary school students' perceptions towards innovative thinking and the relationship of these with various variables according to the survey method of quantitative research methods, an attempt was made to reveal the general states of the students in terms of their perceptions of innovative thinking.

A single survey model revealed a general situation related to the participants' perceptions of innovative thinking. In contrast, a correlational survey model was used to determine whether their perceptions of innovative thinking differed significantly regarding different variables.

\subsection{Study Group}

It is known that the project preparation process allows students to generate new ideas, develops their creativity positively, and has benefits for students such as gaining self-confidence by producing innovations and learning how to cooperate (Atalmıs et al., 2018; Avc1 et al., 2016). Therefore, the study's quantitative data were collected from the participants consisting of $6^{\text {th }}, 7^{\text {th }}$, and $8^{\text {th }}$-grade students who prepared projects for the TÜBITAK 4006 science fair and attended secondary schools participating in the fair during the first semester of the 2018-2019 academic year.

Table 2 Rotated factor loading values and item-total correlation values

\begin{tabular}{|c|c|c|c|c|}
\hline \multirow[t]{2}{*}{ Item No. } & \multicolumn{3}{|c|}{ Rotated Factor Loading Values } & \multirow{2}{*}{$\begin{array}{l}\text { Item-Total Correlation } \\
\text { Values }\end{array}$} \\
\hline & $\begin{array}{l}\text { Innovative } \\
\text { Individual }\end{array}$ & $\begin{array}{l}\text { Traditional } \\
\text { Individual }\end{array}$ & $\begin{array}{l}\text { Inquiring } \\
\text { Individual }\end{array}$ & \\
\hline 2 & .74 & & & .63 \\
\hline 1 & .73 & & & .59 \\
\hline 29 & .65 & & & .55 \\
\hline 20 & .62 & & & .56 \\
\hline 13 & .60 & & & .57 \\
\hline 18 & .60 & & & .43 \\
\hline 31 & .60 & & & .49 \\
\hline 28 & .58 & & & .59 \\
\hline 22 & .56 & & & .56 \\
\hline 3 & .55 & & & .45 \\
\hline 14 & .54 & & & .53 \\
\hline 23 & .45 & & & .53 \\
\hline 27 & & .67 & & .52 \\
\hline 16 & & .62 & & .52 \\
\hline 30 & & .59 & & .44 \\
\hline 24 & & .57 & & .50 \\
\hline 15 & & .55 & & .40 \\
\hline 21 & & .53 & & .41 \\
\hline 32 & & .51 & & .47 \\
\hline 9 & & & .68 & .55 \\
\hline 11 & & & .65 & .53 \\
\hline 7 & & & .62 & .25 \\
\hline 8 & & & .62 & .37 \\
\hline 10 & & & .56 & .40 \\
\hline 19 & & & .54 & .43 \\
\hline Eigenvalues & 7.74 & 1.93 & 1.49 & \\
\hline Percentage of explained variance & 30.96 & 7.74 & 5.97 & \\
\hline Cronbach's alpha & .88 & .76 & .74 & \\
\hline Explained variance for total scale & 44.68 & & & \\
\hline Cronbach's alpha for total scale & .90 & & & \\
\hline
\end{tabular}


Accordingly, to collect the quantitative data of the research, the scale was first administered to a total of 1190 students at five different secondary schools in the center of a city and its districts located in the Black Sea Region. The responses given by 176 students to the scale were considered inconsistent and formed a pattern, which was excluded from the analysis. Moreover, after outliers were also excluded to ensure normal distribution, the data obtained from 831 students were analyzed, and as a result, the study's quantitative findings were obtained as tabulated in Table 1.

\subsection{Data Collection Tools}

Development of Perceptions of Innovative Thinking Scale

Within the scope of the research, the 32-item 'Perceptions of Innovative Thinking Scale,' developed aimed at determining secondary school students' perceptions of innovativeness, was used. However, the large number of items in this scale may decrease students' motivation, and this situation may prevent the likelihood of obtaining valid and correct responses. Considering the age group for whom the scale was developed and the response time of the scale, it was decided to reduce the number of scale items to obtain correct answers (Büyüköztürk, 2005; Erkuş, 2016). An attempt was made to make the item density more readable without impairing the integrity of the items included in the subdimensions by reducing the number of items from 32 to 25 . As it is recommended that in scale development, the implementation should be made with a number of participants between 5 and 10 times the number of items (Büyüköztürk, 2002), the scale with the reduced number of items was administered to 320 students outside the scope of the actual study. As a result of the exploratory factor analysis, it was determined that the scale, which was reduced to 25 items, met the conditions of validity and reliability. As in its original form, it was made up of three subdimensions.

The Kaiser-Meyer-Olkin (KMO) value and Bartlett's test were considered to determine whether the data were suitable for factor analysis. A KMO value of 0.90 was found. This shows that the sample size was excellent. The result of Bartlett's test $(p<0.05)$ showed that factor analysis could be performed with the items in the data set (Pallant, 2020). The factor loading values and item-total correlation values obtained from the exploratory factor analysis are presented in Table 2 .

As can be seen in Table 2, items 1, 2, 3, 13, 14, 18, 20, $22,23,28,29$ and 31 are grouped under factor 1, items 15, $16,21,24,27,30$ and 32 are grouped under factor 2 , and items $7,8,9,10,11$ and 19 are grouped under factor 3, respectively. Item-total correlation values range between 0.25 and 0.63 . Values greater than 0.30 show that the items are differentiated, while cases where values are between 0.20 and 0.30 indicate that the items need to be found based on a requirement in the test or that they need to be revised (Bursal, 2017; Büyüköztürk, 2018). Since the total correlation value of item 7 ('I am afraid of taking risks') was below 0.30 , by obtaining expert opinion, it was changed in such a way as to bear the same meaning to 'I do not feel the need to continually seek different ways to solve a problem.' The rotated factor loading values ranged between 0.47 and 0.68 . Seven items were removed when giving the scale its final form $(4,5,6,12,17,25$, and 26). According to Table 2, the Cronbach alpha values of the total scale and its subdimensions were $0.90,0.88,0.76$, and 0.74 , respectively. Based on these findings, it can be said that the reliability level of the broad-scale and its subfactors are high (Büyüköztürk, 2018). The scale's subfactors that were reduced to 25 items were revised as 'Innovator,' 'Traditionalist,' and 'Open to Enquiry.' The rating statements and their equivalent scores are as follows: Strongly Disagree 1, Disagree 2, Somewhat Agree 3, Agree 4, and Strongly Agree 5. There are 12 positive items (1, 2, $3,9,10,13,15,17,18,21,22,24)$ and 13 negative items (4, $5,6,7,8,11,12,14,16,19,20,23,25)$ in all.

Since the first factor contains statements with which an individual can be characterized as innovative, such as being open to innovations, being able to generate new ideas, being self-confident, being able to use new technologies, and considering social benefit and the national economy, it is given the name 'Innovator'. Examining the second factor, it is considered to recall an individual who can be characterized as a traditionalist. Traditionalist individuals show considerable resistance to innovation and change and regard change, renewal, and innovation as unnecessary. They are characterized by being content with their present situation. They are very uncomfortable with disrupting their habits or conventions, and they display an attitude of indifference to innovations in particular. Considering that its items evoke the characteristics of a traditional individual, the second factor is given the name 'Traditionalist'. When the items belonging to the third subdimension are considered, it is seen that they contain statements such as 'I am undecided about using innovations and new technologies, or 'I worry about trying out new ideas.' It can be seen that these items contain anxiety, indecision, and fear towards innovation and that there is worry and caution regarding innovations. Therefore, the third factor representing these items is 'Open to Inquiry.' Worry and indecision towards an innovation indicate the necessity to question or ponder that innovation. This situation recalls individuals with inquiring characteristics in terms of thinking for a long time and feeling the need for other people's ideas when encountering an innovation.

\subsection{Data Analysis}

The quantitative data obtained in the scope of the research were analyzed on a computer. The data were coded and computerized, and care was taken to code the negative items in reverse. To analyze the data obtained from the 'Perceptions of Innovative Thinking Scale' for 
secondary school students, a normality test was performed to determine whether the data showed a normal distribution. Tabachnick and Fidell (2013) stated that variables taking skewness and kurtosis values between -1.5 and +1.5 could be accepted as showing normal distribution. In order to determine whether or not the secondary school students' perceptions of innovative thinking differed significantly according to the different demographic variables, the parametric MANOVA test was applied since the scale contains three subfactors. To enable the MANOVA test to be performed, multivariate normality wa $\mathrm{s}$ tested in line with the general normality analysis results. By examining the skewness and kurtosis values for normality of the distributions of the dependent variables according to the independent variable categories, the distributions were determined to be normal. The' Mahalanobis distance ' was examined to ensure the condition of multivariate normality. The threshold value was set as 7.815 (Pallant, 2020). The process was repeated by excluding data sources taking values above this value. After the assumption of multivariate normality was met, it was determined that the condition was enabled by examining the appropriateness of the correlation between the dependent variables $(<0.90)$. Equality of covariance was ensured for each independent variable. Finally, as a result of Levene's test, it was determined that the variances for each independent variable were homogeneous. A oneway analysis of variance was performed to determine the source of differences for variables, including more than two groups for which significant differences were determined due to MANOVA analysis. Scheffe's test was used to determine which paired groups there were differences. In order to determine the effect size of the relationship established for the variables, the eta-squared values were examined.

According to Cohen's recommendation, effect sizes of 0.01 are evaluated as small, 0.06 as medium, and 0.14 as large. An attempt was made to explain with tables the mean scores and standard deviation values obtained by the secondary school students participating in the research from the general 'Perceptions of Innovative Thinking Scale' and its subfactors. Moreover, the relationship of the scores obtained by the secondary school students from the 'Innovator', 'Traditionalist', and 'Open to Inquiry' subfactors of the scale with the determined independent variables were examined. The independent variables are gender (1: Female, 2: Male), grade level (1: sixth grade, 2: seventh grade, 3: eighth grade), success grade in science (1: fail, 2: pass, 3: average, 4: good, 5: excellent), participation in the TÜBİTAK science fair (1: participated, 2: did not participate), and state of receiving programming training (1: received, 2: not received). The total innovativeness score was obtained from the scale, and in turn, the scores related to the subdimensions were determined. The lowest score that can be obtained from the scale was determined to be 25 , while the highest obtainable score was determined as 125. To specify intervals in the name of determining the total score obtained from the scale, a standard unit was calculated by dividing the sequence width of the highest and lowest scores obtainable from the scale by the number of options $[(125-25) / 5=20]$, and the intervals were determined approximately according to this unit. Scores obtained from a scale of 86 and over were accepted as high perceptions of innovation by the secondary school students.

In contrast, scores of 85 and below were considered low perceptions of innovation by the students. In terms of the subdimensions of the scale, scores obtained for the 12item 'Innovator' dimension of 40.7 and below were evaluated as negative, while scores of 40.8 and above were assessed as positive. Concerning the 7-item 'Traditionalist' dimensions, scores of 23.7 and under were assessed as negative, while scores of 23.8 and over were evaluated as positive. Finally, for the 'Open to Inquiry' dimension consisting of 6 items, scores of 20.3 and below were negative, while scores of 20.4 and above were regarded as positive.

\section{FINDINGS}

\subsection{Findings Related to Levels of Secondary School Students' Perceptions of Innovative Thinking}

The mean scores and standard deviation values obtained by the students participating in the study from the Perceptions of Innovative Thinking Scale in general and its subfactors were examined.

Descriptive statistical information related to the general distribution of the scores obtained by the students from the 'Perceptions of Innovative Thinking Scale' and its subdimensions is provided in Table 3.

In light of the findings, it was determined that the mean scores obtained by the secondary school students from the Perceptions of Innovative Thinking Scale and its subdimensions were $105.41,49.85,30.87$, and 24.59,

Table 3 Descriptive statistical information related to perceptions of innovative thinking scale mean scores

\begin{tabular}{lllllll}
\hline & $\begin{array}{l}\text { No. of } \\
\text { Items }\end{array}$ & $\begin{array}{l}\text { No. of } \\
\text { Participants }\end{array}$ & Mean & $\begin{array}{l}\text { Standard } \\
\text { Deviation }\end{array}$ & Min. & Max. \\
\hline $\begin{array}{l}\text { Perceptions of Innovative } \\
\text { Thinking }\end{array}$ & 25 & 831 & 105.41 & 11.01 & 77 & 125 \\
Innovator & & & & & & \\
Traditionalist & 12 & 831 & 49.95 & 6.58 & 33 & 60 \\
Open to Inquiry & 7 & 831 & 30.87 & 3.26 & 22 & 35 \\
\hline
\end{tabular}


respectively, and that the scores were high. Moreover, while the lowest score obtained from the whole scale was 77, the highest was 125 .

The correlation matrix, which presents the correlations of the factors and the factor total, is given in Table 4.

Examination of Table 4 shows that the subfactors are correlated with the total score in amounts ranging between .74 and .93 . In the related literature, in determining interfactor correlations, a correlation coefficient between .70 and 1 indicates a high correlation, while a coefficient between .70 and .30 shows moderate correlation (Büyüköztürk, 2018). Accordingly, each factor has a high positive correlation with the factor total, while the subfactors are moderately correlated with each other.

\subsection{Findings Related to Examination of Secondary School Students' Perceptions of Innovativeness According to Gender}

Multivariate analysis of variance (MANOVA) was performed to examine differences between the secondary school students' 'Innovator', 'Traditionalist' and 'Open to Inquiry' scores according to their gender. The findings obtained are presented in Table 5.

The assumption of multivariate normality, which is the precondition of the MANOVA test, was met (Box M Test $=4.933, \mathrm{p}=555)$. When Table 5 is examined, it is seen that the group effect of both the 'Innovator' scores [Wilks' $\lambda=$ $\left.0.988, \mathrm{~F}_{(1.829)}=1.411, \mathrm{p}>0.05\right]$ and the 'Traditionalist' scores [Wilks' $\lambda=0.988, \mathrm{~F}_{(1.829)}=0.607, \mathrm{p}>0.05$ ] of the secondary school students is not significant. In other words, a significant difference was not found between boys' and girls' 'Innovator' or 'Traditionalist' scores. On the other hand, it is seen that the group effect of the secondary school students 'Open to Inquiry' scores is significant $\left[\right.$ Wilks' $\left.\lambda=0.988, \mathrm{~F}_{(1.829)}=4.686, \mathrm{p}<0.05\right]$. However, the effect size value $(\eta 2=0.006)$ was found to be very low. When the mean scores are examined for the source of the difference, it can be seen that males' 'Open to Inquiry' scores $(\underline{X}=24.83)$ are higher than those of females $(\underline{X}=$ 24.38), albeit to a minimal extent.

\subsection{Findings Related to Examination of Secondary School Students' Perceptions of Innovativeness According to Grade Level}

Multivariate analysis of variance (MANOVA) was carried out to examine differences between the 'Innovator', 'Traditionalist', and 'Open to Inquiry' scores of the secondary school students at different grade levels. The findings obtained are shown in Table 6.

The assumption of multivariate normality, which is the precondition of the MANOVA test, was met (Box M Test $=0.859, \mathrm{p}=0.589)$. Examination of Table 6 reveals that the group effect of both the 'Innovator' scores [Wilks' $\lambda=$ $\left.0.978, \mathrm{~F}_{(2.828)}=6.726, \mathrm{p}<0.05\right]$ and the 'Traditionalist' scores [Wilks' $\lambda=0.978, \mathrm{~F}_{(2.828)}=6.473, \mathrm{p}<0.05$ ] of the secondary school students is significant. However, the group effect of the students' 'Open to Inquiry' scores was not found to be significant [Wilks' $\lambda=0.978, \mathrm{~F}_{(2.828)}=2.333$, $\mathrm{p}>0.05]$. The effect size value of both the 'Innovator' ( $\eta 2$ $=0.016)$ and the 'Traditionalist' $(\eta 2=0.015)$ scores was found to be low. When the mean scores are examined for the source of the difference, $6^{\text {th }}$-grade secondary school students' 'Innovator' scores $(X=51.01)$ do not differ significantly from $7^{\text {th }}$-grade students' scores $(\underline{X}=50.01)$. However, they differ significantly from $8^{\text {th }}$-grade secondary

Table 4 Correlation matrix for factors and factor total factor

\begin{tabular}{llll}
\hline & Innovator & Traditionalist & Open to Inquiry \\
\hline Innovator & 1 & .62 & .55 \\
Traditionalist & .62 & 1 & .47 \\
Open to Inquiry & .55 & .47 & 1 \\
\hline Total & .93 & .80 & .74 \\
\hline
\end{tabular}

Table 5 MANOVA results for 'innovator', 'traditionalist', and 'open to inquiry' scores according to gender variable

\begin{tabular}{lllllll}
\hline & KT & Sd & KO & $\mathbf{F}$ & $\mathbf{p}$ & $\boldsymbol{\eta} \mathbf{2}$ \\
\hline Innovator & 61.176 & 1 & 61.176 & 1.411 & 0.235 & 0.002 \\
Traditionalist & 6.467 & 1 & 6.467 & 0.607 & 0.436 & 0.001 \\
Open to Inquiry & 41.957 & 1 & 41.957 & 4.686 & $0.031^{*}$ & 0.006 \\
\hline
\end{tabular}

${ }_{* p}<0.05$

Table 6 MANOVA results for 'innovator', 'traditionalist', and 'open to inquiry' scores according to secondary school students' grade level

\begin{tabular}{|c|c|c|c|c|c|c|}
\hline & KT & Sd & KO & $\mathbf{F}$ & $\mathrm{p}$ & $\eta^{2}$ \\
\hline Innovator & 575.700 & 2 & 287.850 & 6.726 & $0.001 *$ & 0.016 \\
\hline Traditionalist & 136.175 & 2 & 60.088 & 6.473 & $0.002 *$ & 0.015 \\
\hline Open to Inquiry & 41.830 & 2 & 20.915 & 2.333 & 0.098 & 0.006 \\
\hline
\end{tabular}

$*_{\mathrm{p}}<0.05$ 
school students' 'Innovator' scores $(\underline{X}=48.94)$. The reason for this is that $6^{\text {th }}$-grade secondary school students' 'Innovator' scores were found to be higher than $8^{\text {th }}$-grade secondary school students' 'Innovator' scores. When examined in terms of the 'Traditionalist' scores, it is seen that $6^{\text {th }^{\mathrm{h}} \text {-grade }}$ secondary school students' scores $(\underline{X}=$ 31.32) do not differ from $7^{\text {th }}$-grade students' scores $(\underline{X}=$ $31.00)$, whereas they differ significantly from $8^{\text {th }}$-grade students' scores $(\underline{X}=30.34)$. It was determined that $6^{\text {th }}$ grade students' 'Traditionalist' scores are higher than $8^{\text {th }}$ grade students' 'Traditionalist' scores.

\subsection{Findings Related to Examination of Secondary School Students' Perceptions of Innovativeness According to Success Grades in the Subject of Science}

Multivariate analysis of variance (MANOVA) was performed to examine whether there were differences between the 'Innovator', 'Traditionalist' and 'Open to Inquiry' scores of the secondary school students who had different success grades in the subject of science. The findings obtained are presented in Table 7.

The assumption of multivariate normality, which is the precondition of the MANOVA test, was met (Box M Test $=0.621, \mathrm{p}=0.923)$. When Table 7 is examined, it is seen that the group effect of all the 'Innovator' [Wilks' $\lambda=0.922$, $\left.\mathrm{F}_{(4.826)}=10.564, \mathrm{p}<0.05\right]$, 'Traditionalist' [Wilks' $\lambda=0.922$, $\mathrm{F}_{(4.826)}=13.565, \mathrm{p}<0.05$ ] and 'Open to Inquiry' [Wilks' $\lambda$ $\left.=0.922, \mathrm{~F}_{(4.826)}=9.156, \mathrm{p}<0.05\right]$ scores is significant. The effect size value of both the 'Innovator' $(\eta 2=0.049)$ and 'Open to Inquiry' $(\eta 2=0.041)$ scores were found to be low, while that of the 'Traditionalist' $(\eta 2=0.062)$ scores was found to be moderate. When the mean scores are examined in terms of the source of the difference, the 'Innovator' scores of students with average grades in science $(\underline{X}=$ 48.82) differ significantly from scores of students who failed $(X=43.75)$. The 'Innovator' scores of students with good grades in science $(\underline{X}=48.97)$ differ significantly from scores of students who failed $(\underline{X}=43.75)$. Finally, the 'Innovator' scores of students with excellent grades in science $(X=50.91)$ also differ significantly from scores of students who failed $(X=43.75)$. Examination of the 'Traditionalist' scores reveals that the 'Traditionalist' scores of secondary school students with average grades in science $(\underline{X}=30.15)$ differ significantly from students who failed $(\underline{X}=27.58)$. The 'Traditionalist' scores of secondary school students with good grades in science $(\underline{X}=30.30)$ also differ significantly from scores of students who failed $(\underline{X}=$ 27.58). The 'Traditionalist' scores of secondary school students with excellent grades in science $(\underline{X}=31.42)$ differ significantly from scores of students who failed ( $\underline{X}=$ 27.58), scores of those with average grades $(X=30.15)$, and scores of those with good grades $(\underline{X}=30.30)$. When the 'Open to Inquiry' scores are examined, it can be seen that the 'Open to Inquiry' scores of secondary school students with excellent grades in science $(X=25.04)$ differ significantly from scores of students with good grades ( $\underline{X}$ $=24.14)$, scores of those with pass grades $(\underline{X}=23.35)$, and scores of those who failed $(\underline{X}=22.70)$. It was determined that secondary school students with excellent grades in science have higher 'Open to Inquiry' scores than secondary school students with good and pass grades and students who failed.

\subsection{Findings Related to Examination of Secondary School Students' Perceptions of Innovativeness According to State of Participation in TÜBITAK Science Fair}

Multivariate analysis of variance (MANOVA) was carried out to examine whether there were differences between the 'Innovator', 'Traditionalist' and 'Open to Inquiry' scores of the secondary school students according to whether or not they had participated in the TÜBİTAK 4006 science fair. The findings obtained are shown in Table 8.

The assumption of multivariate normality, which is the precondition of the MANOVA test, was met (Box M Test $=1.431, \mathrm{p}=0.198)$. Examination of Table 8 shows that the

Table 7 MANOVA results for 'innovator', 'traditionalist', and 'open to inquiry' scores according to science success grades variable

\begin{tabular}{lllllll}
\hline & KT & Sd & KO & F & p & 盂 \\
\hline Innovator & 1752.494 & 4 & 438.123 & 10.564 & $0.001^{*}$ & 0.049 \\
Traditionalist & 545.245 & 4 & 136.311 & 13.565 & $0.000^{*}$ & 0.062 \\
Open to Inquiry & 316.923 & 4 & 79.231 & 9.156 & $0.000^{*}$ & 0.041 \\
\hline
\end{tabular}

$* \mathrm{p}<0.05$

Table 8 MANOVA results for 'innovator', 'traditionalist', and 'open to inquiry' scores according to variable of participation in tübitak 4006 science fair

\begin{tabular}{lllllll}
\hline & KT & Sd & KO & F & p & $\eta^{2}$ \\
\hline Innovator & 1334.216 & 1 & 1334.216 & 31.898 & $0.000^{*}$ & 0.037 \\
Traditionalist & 201.124 & 1 & 201.124 & 19.289 & $0.000^{*}$ & 0.023 \\
Open to Inquiry & 108.724 & 1 & 108.724 & 12.253 & $0.000^{*}$ & 0.015 \\
\hline
\end{tabular}

$*_{p}<0.05$ 
Table 9 MANOVA results for 'innovator', 'traditionalist', and 'open to inquiry' scores according to variable of receiving programming training

\begin{tabular}{|c|c|c|c|c|c|c|}
\hline & KT & Sd & KO & F & $\mathrm{p}$ & $\eta 2$ \\
\hline Innovator & 532.343 & 1 & 532.343 & 12.440 & $0.000 *$ & 0.015 \\
\hline Traditionalist & 65.907 & 1 & 65.907 & 6.223 & $0.013^{*}$ & 0.007 \\
\hline Open to Inquiry & 59.037 & 1 & 59.037 & 6.609 & $0.010^{*}$ & 0.008 \\
\hline
\end{tabular}

${ }_{\mathrm{p}}<0.05$

group effect of all the 'Innovator' [Wilks' $\lambda=0.961, \mathrm{~F}_{(1.829)}$ $=31.898, \mathrm{p}<0.05]$, 'Traditionalist' [Wilks' $\lambda=0.961, \mathrm{~F}_{(1.829)}$ $=19.289, \mathrm{p}<0.05$ ] and 'Open to Inquiry' [Wilks' $\lambda=0.961$, $\left.\mathrm{F}_{(1.829)}=12.253, \mathrm{p}<0.05\right]$ scores is significant. The effect size value of all the 'Innovator' $(\eta 2=0.037)$, 'Traditionalist' $(\eta 2=0.023)$ and 'Open to Inquiry' scores $(\eta 2=0.015)$ was found to be low. When the mean scores are examined in terms of the source of the difference, it is seen that the scores of the students who took part in the science fair are higher than scores of those who did not participate with regard to their 'Innovator' scores $(\underline{X}=52.16, \underline{X}=49.22$, respectively), 'Traditionalist' scores $(\underline{X}=31.73, \underline{X}=30.59$, respectively), and 'Open to Inquiry' scores $(\underline{X}=25.22, \underline{X}=$ 24.39, respectively).

\subsection{Findings Related to Examination of Secondary School Students' Perceptions of Innovativeness According to State of Receiving Programming Training}

Multivariate analysis of variance (MANOVA) was carried out to examine differences between the 'Innovator', 'Traditionalist' and 'Open to Inquiry' scores of the secondary school students according to whether or not they had received programming training. The findings obtained are presented in Table 9.

The assumption of multivariate normality, which is the precondition of the MANOVA test, was met (Box M Test $=0.347, \mathrm{p}=0.912)$. When Table 9 is examined, it is seen that the group effect of all the 'Innovator' [Wilks' $\lambda=0.984$, $\left.\mathrm{F}_{(1.829)}=12.440, \mathrm{p}<0.05\right]$, 'Traditionalist' [Wilks' $\lambda=0.984$, $\left.\mathrm{F}_{(1.829)}=6.223, \mathrm{p}<0.05\right]$ and 'Open to Inquiry' [Wilks' $\lambda=$ $\left.0.984, \mathrm{~F}_{(1.829)}=6.609, \mathrm{p}<0.05\right]$ scores is significant. The effect size value of the 'Innovator' $(\eta 2=0.015)$ scores was found to be low, while in terms of the 'Traditionalist' ( $\eta 2$ $=0.007)$ and 'Open to Inquiry' scores $(\eta 2=0.008)$, it was found to be very low. When the mean scores are examined in terms of the source of the difference, is can be seen that the scores of the students who received programming training are higher than scores of those who did not receive it in terms of their 'Innovator' scores $(\underline{X}=51.03, \underline{X}=49.35$, respectively), 'Traditionalist' scores $(\underline{X}=31.25, \underline{X}=30.66$, respectively), and 'Open to Inquiry' scores ( $\underline{X}=24.95, \underline{X}=$ 24.40, respectively).

\section{DISCUSSION}

In this study, which was conducted to determine the innovativeness of secondary school students in their science lessons, it was determined that the secondary school students' perceptions towards innovative thinking were high and that in terms of the subdimensions, their mean scores in the 'Innovator', 'Traditionalist' and 'Open to Inquiry' subdimensions were also positive and high. This finding corresponds with the findings of the study by Deveci and Kavak (2020), in which $46 \%$ of students showed a high innovative thinking tendency. Accordingly, it can be said that the students in the sample were generally open to innovation and change. The increase in students' interest in technology nowadays can be given as a reason for this. Therefore, it is considered that teachers should have innovative characteristics and that they can frequently include innovative teaching methods-techniques and technology in their classes. Moreover, factors such as parents' knowledgeableness and high-income levels due to their professions may also come into play.

When examined in terms of the gender factor, it was determined that while there was no significant difference for the 'Innovator' and 'Traditionalist' factors, there was an effect on the 'Open to Inquiry' factor in favor of boys albeit at a very low level. Similar to these findings, it was revealed that gender did not make a significant difference to innovativeness (Deveci \& Kavak, 2020), creativity (Dilek, 2013; Kanl1, 2017; Midilli, 2019), entrepreneurship (Deveci, 2018), problem-solving skills (Özbulak, Aypay, \& Aypay, 2011), or critical thinking (Akar \& Kara, 2016). However, the fact that significant differences were determined in secondary school students' creativity (Barışık, 2019), $21^{\text {st. }}$ century learning skills (Bozkurt \& Çakır, 2016), scientific inquiry perceptions (İnel-Ekici, 2016), and critical thinking skills (Köksal \& Çöğmen, 2018), in favor of females, conflicts with the findings of this study. Öztürk et al. (2019) stated the reason why the entrepreneurial characteristic does not differ significantly according to gender, that together with the increase in their education level, females are claiming their place in the world of entrepreneurship, and that in the $21^{\text {st }}$ century, families in our country are offering similar opportunities without gender discrimination.

The fact that gender did not significantly differ from the 'Innovator' and 'Traditionalist' scores may be because the students had more or less the same opportunities in the areas where they grew up. Moreover, rather than gender, the family's education level, school facilities, and teachers' and administrators' innovative characteristics may have affected the 'Innovator' and 'Traditionalist' scores. Therefore, it can be thought that families with a high 
education level will also have high levels of innovativeness, and their children will also have high innovativeness levels.

When the grade level variable was examined, it was determined that while there was a significant difference concerning the 'Innovator' and 'Traditionalist' subdimensions, a significant difference did not occur regarding the 'Open to Inquiry' subfactor. Sixth-grade students' 'Innovator' and 'Traditionalist' scores were determined to be higher than eighth-grade students' scores. In the literature, the finding that the use of $21^{\text {st-century }}$ skills decreased as grade level increased (Bozkurt \& Çakır, 2016) corresponds with the finding of this study. However, the fact that creativity (Barış1k, 2019), perceptions towards problem-solving skills (Tunç \& Taşgin, 2018), and critical thinking skills (Çakırlar-Altuntaş, Yılmaz, \& Turan, 2017) did not vary according to grade level conflicts with this finding. One of the reasons why the secondary school students' 'Innovator' scores decreased as grade level increased may be the fact that secondary school students focus on solving tests rather than activities and experiments in their lessons in order to prepare for the high school placement examinations (Bozkurt \& Çakır, 2016). It can be thought that teachers and parents also encourage students mainly to prepare for the examinations.

When considered in terms of the 'Innovator' dimension, it was determined that the 'Innovator' scores of students with high success grades in the subject of science differed significantly from the scores of those with other success grades. When the literature is examined, it was stated in the literature that creativity levels were high in students with good science grades (Erdoğdu \& Şirin, 2018; K1lıç \& Tezel, 2012; Baysal et al., 2013), entrepreneurship tendencies were high in students with high academic achievement (Deveci, 2018), problem-solving skills were high in students with high achievement in science (Durgun \& Önder, 2019), and innovativeness tendencies were high in students with high perceptions of scientific inquiry skills (Inel-Ekici, 2016) and in academically successful students (Deveci \& Kavak, 2020). These findings correspond with the findings of the present study. Deveci and Kavak (2020) reported that successful students asked more questions than others. Since they generated creative ideas, the fact that their tendencies towards innovative thinking were also high was an expected result. Inel-Ekici (2016) stated that perceptions towards innovativeness were high since teachers included inquiry-based activities in their lessons and that students who were highly successful in science also showed active participation in this process.

When examined in terms of participation in the TÜBİTAK 4006 science fair, a significant difference was found in students' 'Innovator', 'Traditionalist' and 'Open to Inquiry' mean scores in favor of those who took part in the science fair. Similar to this finding, Yildirım (2018) revealed that problem-solving skills developed in students who participated in science festivals, Çavuş, Balçın, and Yılmaz
(2018) reported that science fair activities increased secondary school students' perceptions of problem-solving skills, and Soyuçok (2018) stated that communication and creativity skills developed in students who created projects by taking part in science fairs. It was determined that science fairs reduce students' anxiety towards the subject of science and also have a positive effect on their motivation (Keskin, 2019), that they have positive benefits for students' inquiry skills, and that they increase students' interest and achievement in the subject of science (Soyuçok, 2018). Project-based learning methods will support the education of students as individuals who are curious, investigate, inquire, solve the problems they encounter, and think critically and creatively (Avc1 \& SuÖzenir, 2018; Seechaliao, 2017, Siew \& Ambo, 2018). Accordingly, the fact that 'Innovator' and 'Open to Inquiry' scores were high is an expected result. The reason why the 'Traditionalist' scores of students who participated in the science fair were also high maybe because innovative thinking skills had only recently been added to the curriculum.

The 'Innovator', 'Traditionalist' and 'Open to Inquiry' scores of students who had received programming training were higher than those who had not received it. This finding shows similarity with the findings that for students receiving programming training, their problem-solving, creative, and innovative thinking skills developed (Başarmak \& Hamutoğlu, 2019). In addition, the training enabled their creativity and digital thinking skills, ability to identify problems and solve the problems they identified, design skills, and ability to think multilaterally (Göksoy \& Yllmaz, 2018). Considering the interest in technology shown by students nowadays, it can be thought that the programming training they received also attracted their interest. Therefore, the process was experienced productively. On the other hand, the reason why the 'Traditionalist' scores of students who received programming training were also high maybe because some teachers were not sufficiently equipped (Mihc1-Türker \& Pala, 2018), that some school principals did not have adequate knowledge (Ünsal, 2019), and that reasons such as these led students to regard programming as a simple game.

\section{CONCLUSION}

It was determined that the students generally possessed innovative personality traits, paid regard to social benefit, and were open to innovation and development. Findings reveal that the secondary school students were open to innovation and change, possessed innovative traits, and gave importance to social benefit; in short, they were innovators.

Moreover, it was concluded that the increasing importance given to innovativeness nowadays, projectbased learning aimed at developing innovativeness in the 
education process, different teaching practices such as STEM, and the inclusion of technology in the process, have positive effects on students' innovativeness.

It was revealed that sixth-grade students' 'Innovator 'scores were higher than those of eighth grade students. It can be said that because students prepared for high school placement examinations and focused on answering test questions, their innovativeness decreased as grade level increased. Considering the positive effect on innovativeness of involvement in project work, practices towards finding solutions to everyday problems can be included in eighth grade students' lessons to contribute positively to their innovativeness.

Although the students who took part in the study were at ages when abstract thinking skills began to develop, concrete products are essential for their better interpretation. Consequently, experiencing the process of including STEM or programming activities and project work is important for contributing to students' innovativeness. Therefore, it can be recommended that science teachers provide the necessary opportunities.

Teachers should serve as a guide to students in their activities such as project preparation and should not help them achieve results by gravitating towards highly successful students in lessons and offering them readymade project ideas. Instead, more encouragement should be given, especially to students with low achievement in lessons and whose creative and innovative thinking skills are not sufficiently developed. Moreover, in the process, students should be given opportunities to generate ideas such as identifying the problem, developing solution suggestions, and putting these ideas into practice.

\section{ACKNOWLEDGMENT}

This article is generated from the master thesis of the first author.

\section{REFERENCES}

Açıkgöz-Ersoy, B., \& Muter-Şengül, C. (2008). Yenilikçiliğe yönelik devlet uygulamaları ve AB karşılaştırması [Government applications towards innovation and comparison with European Union]. Journal of Management and Economics, 15(1), 59-74.

Akar, C., \& Kara, M. (2016). İlkokul 4. sınıf öğrencilerinin eleştirel düşünme becerilerinin bazı değişkenlere göre değerlendirilmesi [The evaluation of 4 ht elementary school students' critical thinking skills in terms of some variables]. International Journal of Turkish Literature Culture Education, 5(3), 1339-1355.

Akkaya, D. (2016). Illkögretim 7. sme ögrencilerinin inovasyon becerilerinin degerlendirilmesi [Evaluation of innovation skills of $7^{\text {th }}$ grade primary school students]. (Unpublished master's thesis). University of Adnan Menderes.

Aldahdouh, T. Z., Nokelainen, P., \& Korhonen, V. (2020). technology and social media usage in higher education: The influence of individual innovativeness. $S A G E$ https://doi.org/10.1177/215824401989944

Open, 10(1)

Atalmış, E. H., Selçuk, G., \& Ataç, A. (2018). TÜBİTAK 4006 projelerine ilişkin yönetici, yürütücü ve öğrenci görüşleri [Manager, executive and student views on TUBITAK 4006 projects]. Kirsehir Journal of Education, 19(3), 1999-2020. http://dx.doi.org/10.29299/kefad.2018.19.03.006
Atamanova, I., \& Bogomaz, S. (2021). Value and activity-based orientations of university students: The choice between safety and innovativeness. Science, 11(1), $59-74$ http://dx.doi.org/10.15293/2658-6762.2101.04

Avc1, E., Su-Özenir, Ö., \& Yücel, E. (2016). TÜBİTAK ortaöğretim öğrencileri araştırma projeleri yarışmasına katılan öğrencilerin yarışma sonrası kazanımlarının incelenmesi [Students' experiences during TUBITAK secondary education students' research projects competition and its contribution to their university life]. Uşak University Journal of Social Sciences, 9(27/3), 1-21.

Avcı, E., \& Su-Özenir, S. (2018). Bilim fuarları sürecinin yürütücü öğretmenler gözünden değerlendirilmesi [Evaluation of science fair process from project coordinator teachers' point of view]. Elementary Education Online, 17(3), 1672-1690. https://doi.org/10.17051/ilkonline.2018.466417

Aytekin, A., Sönmez-Çakır, F., Yücel, Y. B., \& Kulaözü, İ. (2018). Geleceğe yön veren kodlama bilimi ve kodlama öğrenmede kullanılabilecek bazı yöntemler [Coding science directed to future and some methods to be available, and coding learned]. Eurasian Journal of Social and Economic Research, 5(5), 24-41.

Barış1k, A. (2019). Ortaokul ögrencilerinin benlik saygular ve yaratıc düsünme becerilerinin çeşitli değişkenler açısından incelenmesi Istanbul ili örneği [Examination of secondary school students' self-esteem and creative thinking skills in terms of various variables the sample of İstanbul province]. (Unpublished master's thesis). University of Çă̆.

Başarmak, U., \& Hamutoğlu, N. B. (2019). Ortaokul öğrencilerinin "KOD Adı 2023" projesi eğitimine yönelik görüşleri [Secondary school students' opinions on "KOD Ad1 2023" project education]. Gazi Journal of Educational Sciences, 5(Special issue), 55-66. https://doi.org/10.30855/gjes.2019.os.01.004

Bautista, R. G. (2021). Project Kinang: A Gem In Advancing The Individual Innovativeness Of Pre-Service Secondary School Teachers. Turkish Journal of Computer and Mathematics Education (TURCOMAT), 12(3), 5265-5278.

Bayrakçı, M., \& Eraslan, F. (2014). Ortaöğretim okul yöneticilerinin inovasyon yeterlilikleri [Innovation competencies of highschool administrator]. Sakarya University Journal of Education Faculty, (28), 96-135.

Baysal, Z. N., Kaya, N. B., \& Üçüncü, G. (2013). İlkokul dördüncü sınıf öğrencilerinde bilimsel yaratıcılık düzeyinin çeşitli değişkenler açısından incelenmesi [Examining the level of scientific creativity in primary school fourth grade students in terms of various variables]. Eğitim Bilimleri Dergisi, 38, 55-64.

Bozkurt, Ş. B., \& Çakır, H. (2016). Ortaokul öğrencilerinin 21. yüzyıl öğrenme beceri düzeylerinin cinsiyet ve sınıf seviyesine göre incelenmesi [ $21^{\text {st }}$ century learner skills: an investigation of middle school students based on grade level and gender]. Pamukkale University Journal of Education,39(39), 69-82. https://doi.org/10.9779/PUJE757

Bursal, M. (2017). SPSS ile temel veri analizleri [Basic data analysis with SPSS]. Anı Yayıncilik.

Büyüköztürk, Ş. (2002). Faktör analizi: Temel kavramlar ve ölçek geliştirmede kullanımı [Factor analysis: Basic concepts and its use in scale development]. Educational Administration - Theory and Practice, 8(4), 470-483.

Büyüköztürk, Ş. (2005). Anket geliştirme [Survey development]. Türk Eğitim Bilimleri Dergisi, 3(2), 133-151.

Büyüköztürk, Ş. (2018). Sosyal bilimler için veri analizi el kitabı, istatistik, arastrma deseni spss uygulamalar ve yorum [Data analysis handbook for social sciences, statistics, research design spss applications and interpretation]. Pegem Akademi.

Çakırlar-Altuntaș, E., Yılmaz, M., \& Turan, S. L. (2017). Biyoloji öğretmen adaylarının eleştirel düşünme eğilimleri üzerine bir inceleme [An investigation on critical thinking tendencies of preservice biology teachers]. Ege Journal of Education, 19(1), 34-45. https://doi.org/10.12984/egeefd.306019 
Çavuş, R., Balçın, M. D., \& Yılmaz, M. M. (2018). Bilim fuarı etkinliklerinin ortaokul öğrencilerinin fen ve problem çözme becerilerine yönelik algilarına etkisi [The effect of science fair activities on secondary school students' perceptions of science and problem-solving skills]. Inonu University Journal of the Graduate School of Education, 5(10), 1-17. https://doi.org/10.29129/inujgse.395132

Daghfous N., Petrof J.V., \& Pons F. (1999). Values and adoption of innovations: a cross cultural study. Journal of Consumer Marketing, 16(4), 314-331.

Demir-Başaran, S., \& Keleş, S. (2015). Yenilikçi kimdir? Öğretmenlerin yenilikçilik düzeylerinin incelenmesi [Who is innovative? Examination of teachers' innovativeness level]. Hacettepe University Journal of Education, 30(4), 106-118.

Demirel, Y., \& Seçkin, Z. (2008). Bilgi ve bilgi paylaşımının yenilikçilik üzerine etkileri [The impact of knowledge and knowledge sharing on innovation]. Cukurova University Journal of Institute of Social Sciences, 17(1), 189-202.

Deveci, İ. (2018). Ortaokul öğrencilerine yönelik fen tabanlı girișimcilik ölçeği: Geçerlik ve güvenirlik çalışması [Science-based entrepreneurship scale for middle school students: A validity and reliability study]. Journal of Multidisciplinary Studies in Education, 2(1), $1-15$.

Deveci, İ., \& Kavak, S. (2020). Ortaokul öğrencilerinin yenilikçilik algıları ve yenilikçi düşünme eğilimleri: Bir keşfedici ardışık desen Innovativeness perceptions and innovative thinking tendencies of middle school students: An exploratory sequential design]. Journal of Qualitative Research in Education, 8(1), 346-378. https://doi.org/10.14689/issn.2148-2624.1.8c.1s.15m

Dilek, A. N. (2013). Sosyo-kültürel özelliklerin yaratıc düsünmeye etkisi [The impact of socio-cultural features on creative thinking] (Unpublished master's thesis). University of Osmangazi.

Durgun, E., \& Önder, İ. (2019). Ortaokul 7. sınıf öğrencilerinin fen bilimleri başarıları ile okuduğunu anlama, grafik okuma ve sorun çözme becerileri arasındaki ilişki [The relationship of science achievement with reading comprehension, graphic reading, problem solving skills in middle school seventh grade students]. Journal of Individual Differences in Education, 1(1), 1-13.

Erdoğdu, M. Y., \& Sirin, T. (2018). İlkokul öğrencilerinin yaratıcılıkları ile ahlaki olgunluk ve akademik başarı ilişkisi [The relationshıp of empathy moral maturity and academic achievement with the development of primary school students' creativeness]. Electronic Turkish Studies, 13(19), 681-696. https://doi.org/10.7827/TurkishStudies.13746

Erkuş, A. (2016). Psikoloji ölçme ve ölgek geliştirme-I: Temel kavramlar ve işlemler [Psychology measurement and scale development-I: Basic concepts and operations]. Pegem Akademi.

Gök, B., \& Erdoğan, T. (2011). Sınıf öğretmeni adaylarının yaratıcı düşünme düzeyleri ve eleştirel düşünme eğilimlerinin incelenmesi The investigation of the creative thinking levels and the critical thinking disposition of pre-service elementary teachers]. Ankara University Journal of Faculty of Educational Sciences, 44(2), 29-51.

Göksoy, S., \& Yılmaz, İ. (2018). Bilişim teknolojileri öğretmenleri ve öğrencilerinin robotik ve kodlama dersine ilişkin görüssleri [The opinions of information relations teacher and their students with regard to lessons of robots and decoding]. Journal of Düzce University Institute of Social Sciences, 8(1), 178-196.

İnel-Ekici, D. (2016). Ortaokul öğrencilerinin bilimsel sorgulama becerileri algılarını etkileyen faktörlerin incelenmesi [A study on the factors affecting secondary school students' scientific research skills perceptions]. Kastamonu Education Journal, 25(2), 497-516.

Kanlı, E. (2017). Üstün yetenekli öğrencilerin bilimsel yaratıcıllk düzeyleri, cinsiyet ve bilimsel tutumları arasındaki ilişkilerin incelenmesi [Investigating the relations between scientific creativity, gender and scientific attitudes of gifted learners]. Elementary Education Online, 16(4), 1792-1802. https://doi.org/ 10.17051/ilkonline.2017.342992

Kasapoğlu, H. (2018). Üniversite yöneticilerinin yenilikçilik ve risk alma davranışlarına ilişkin yönetici ve öğretim elemanlarının görüşleri
[The views of administrators and academic staff about the innovativeness and risk-taking behaviors of university administrators]. Journal of Higher Education, 8(1), 45-54. https://doi.org/10.2399/yod.18.001

Kavacık, L., Yanpar-Yelken, T. \& Sürmeli, H. (2015). İlköğretim fen ve teknoloji dersinde inovasyon (yenilikçi) proje uygulamaları ve öğrenciler üzerindeki etkileri [nnovation (innovative) project applications in primary science and technology lesson and its effects on students]. Education and Science, 40(180), 247-263. http://dx.doi.org/10.15390/EB.2015.2613

Keskin, D. (2019). Bilim fuarlarmm ortaokul ögrencilerinin bilimsel süres becerileri, fen dersine karsu motivasyonlar ve kayg düzeyleri üzerinde etkisi [The effect of science fairs on science process skills, motivation and anxiety levels of secondary school students]. (Unpublished master's thesis). University of Pamukkale.

Kılıç, B., \& Tezel, Ö. (2012). İlköğretim sekizinci sınıf öğrencilerinin bilimsel yaratıcıllk düzeylerinin belirlenmesi [Determining scientific creativity levels of $8^{\text {th }}$ grade students]. Türk Fen Eğitimi Dergisi, 9(4), 84-101.

Kılıçer, K., \& Odabaşı, H. F. (2010). Bireysel yenilikçilik ölçeği (BYÖ): Türkçeye uyarlama, geçerlik ve güvenirlik çalş̧ması [Individual innovativeness scale (IS): The study of adaptation to Turkish, validity and reliability]. Hacettepe University Journal of Education, 38(38), 150-164.

Kinay, I., \& Suer, S. (2020). Investigation of relationship between prospective teachers' learning beliefs and state of individual innovativeness. Cypriot Journal of Educational Sciences, 15(3), 604-618 https://doi.org/10.18844/cjes.v15i3.4642

Köksal, N., \& Çöğmen, S. (2018). Ortaokul öğrencilerinin eleştirel düşünme ve iletissim becerileri [Critical thinking and communication skills of secondary school students]. Pamukkale University Journal of Education, 44, 278-296. https://doi.org/ 10.9779/PUJE.2018.218

Menold, J., Jablokow, K., Purzer, S., Ferguson, D. M., \& Ohland, M. W. (2014, June). A critical review of measures of innovativeness. In 2014 ASEE Annual Conference \& Exposition (pp. 24-41).

Mrhci-Türker, P., \& Pala, F. K. (2018). Ortaokul öğrencilerinin, öğretmenlerin ve öğrenci velilerinin kodlamaya yönelik görüşleri [Opinions of secondary school students, teachers and parents about coding]. Elementary Education Online, 17(4), 2013-2029. https://doi.org/ 10.17051/ilkonline.2019.506939

Midilli, M. (2019). Özel yetenekli ilkokul ögrencilerinin yaratıc düsünme becerilerinin baž değşskenlere göre incelenmesi [Invastigation of gifted primary school students' creative thinking skills in terms of some variables]. (Unpublished master's thesis). University of Ordu.

Mikhailova, O. B. (2019). High school students involved and not involved in MMORPG: Creativity and innovativeness. International Journal of Cognitive Research in Science, Engineering and Education, 7(2), 29-39.

MoNE (Turkey Ministry of National Education). (2018). Science course curriculum (Primary and Secondary 3, 4, 5, 6, 7, and 8 Grades). http:// mufredat.meb.gov.tr/ProgramDetay.aspx?PID $=325$

Nguyen, D., Pietsch, M., \& Gümüş, S. (2021). Collective teacher innovativeness in 48 countries: Effects of teacher autonomy, collaborative culture, and professional learning. Teaching and Teacher Education, 106, https://doi.org/10.1016/j.tate.2021.103463

Ögüt, A., Aygen, S., \& Demirsel, M. T. (2007). Personel güçlendirme inovasyonu hızlandırır mi? Antalya ili beş yıldızlı konaklama işletmelerine yönelik görgül bir araştırma [Will staff empowerment accelerate innovation? An empirical research on five-star accommodation establishments in Antalya]. Selçu Üniversitesi Karaman İktisadi ve İdari Bilimler Fakültesi Dergisi, Special issue, 163172.

Özbulak, B. E., Aypay, A., \& Aypay, A. (2011). Ortaöğretim öğrencilerinin problem çözme ve atılganlık becerilerinin bazı değişkenlerle ilişkisi [High school students' problem solving and 
assertiveness skills and their relationships with some variables]. Electronic Journal of Social Sciences, 10(36), 77-93.

Öztürk, E., Önder, A. N., \& Güven-Yıldırım, E. (2019). Fen bilgisi öğretmen adaylarının girișimcilik özelliklerinin ve eleștirel düșünme eğilimlerinin bazı değişkenler açısından incelenmesi [Investigation of prospective science teachers' entrepreneurship characteristics and critical thinking dispositions in terms of some variables]. Journal of Individual Differences in Education, 1(2), 89-107.

Pallant, J. (2020). SPSS Survival Manual: A step-by-step guide to data analysis using IBM SPSS. Routledge.

Parlar, H., Polatcan, M., \& Cansoy, R. (2019). The relationship between social capital and innovativeness climate in schools: The intermediary role of professional learning communities. International Journal of Educational Management. https://doi.org/10.1108/IJEM-10-2018-0322

Polat, M. (2017). Simf ögretmenlerinin elesstirel düsünme eğilimleri ile yaratccllke. düzeylerinin bazı değiskenlere göre incelenmesi [Examining primary school teachers'critical thinking disposition and creativity levels in terms of difference variable]. (Unpublished master's thesis). University of Adiyaman.

Rıza, E. T. (1999). Yaratıchlı̆ gelistirme teknikleri [Techniques for enhancing creativity]. Anadolu Press.

Rogers, M. E. (1995). Diffusion of Innovations (Fifth Edition). Free Press.

Sarı, I., \& Kartal, F. (2018). Sosyal bilgiler öğretmen adaylarının teknoloji ile ilgili tutumlarının bireysel yenilikçilik düzeyleri ve bazı değişkenler açısından incelenmesi [Investigation of social studies teacher candidates' attitudes towards using technology in terms of individual innovativeness levels and some variables]. Kirșehir Journal of Education, 19(2), 1673-1689. https://doi.org/10.29299/kefad.2018.19.02.017

Seechaliao, T. (2017). Instructional strategies to support creativity and innovation in education. Journal of Education and Learning, 6(4), 201 208 http://doi.org/10.5539/jel.v6n4p201

Siew, N. M., \& Ambo, N. (2018). Development and evaluation of an integrated project-based and STEM teaching and learning module on enhancing scientific creativity among fifth graders. Journal of Baltic Science Education, 17(6), 1017 http://doi.org/10.33225/jbse/18.17.1017

Soyuçok, H. (2018). TÜBITTAK 4006 bilim fuarlar kapsamında bazırlanan fen projeleri hak.kinda çalısmalara katılan farkh kesimlerin görüsleri [Views of different participants in studies about science projects prepared in scope of TUBITAK 4006 scientific fairs]. (Unpublished master's thesis). University of İbrahim Çeçen.

Tabachnick, B. G., \& Fidell, L. S. (2013). Using Multivariate Statistics (6 $\left.6^{\text {th }}\right)$. Pearson Education.

Tunç, Y., \& Taşgin, A. (2018, November). Examination of middle school students' perceptions of problem-solving skills [Abstract presentation]. Iğdır International Conference on Multidisciplinary Study, Iğdır, Turkey.

Ulusoy-Yılmaz, D., \& Yıldız, Y. (2019). Müzik öğretmen adaylarının yaratıcı düşünme becerilerinin çeşitli değişkenler açısından incelenmesi [Investigation of creative thinking skills of music teacher candidates in terms of various variables]. Cumburiyet International Journal of Education, 8(2), 516-530. http://dx.doi.org/10.30703/cije.522714

Ünsal, K. (2019). Ortaokul ve lise okul yöneticilerinin kodlama eğitimine yönelik görüslerinin incelenmesi (Bağcalar ilçesi örneği) [Investigation of secondary and high school pirincipals' opinions on coding training (Sample of Bagcilar district)]. (Unpublished master's thesis). University of Sabahattin Zaim.

Yenice, N., \& Alpak-Tunç, G. (2019). Öğretmen adaylarının yaşam boyu öğrenme eğilimleri ile bireysel yenilikçilik düzeylerinin incelenmesi [An investigation of pre-service teachers' lifelong learning tendencies and their individual innovativeness levels]. Kastamonu Education Journal, 27(2), 753-765. https://doi.org/10.24106/kefdergi.2716

Yıldırım, B. (2018). STEM uygulamalarına yönelik öğretmen görüşlerinin incelenmesi [Research on teacher opinions on stem

DOI: $10.17509 / j$ sl.v5i1.33533 practices]. Journal of Education Theory and Practical Research, 4(1), 4253

Yllmaz-Öztürk, Z. (2015). İlköğretim okulu ögretmenlerinin bireysel yenilikçilik düzeyleri ve bu düzeylere etki eden etmenlerin incelenmesi [An analysis of primary school teachers' level of individual innovativeness and the factors affecting it]. (Unpublished doctoral dissertation). University of Gaziantep.

Yoon, S. (2018). A Study on the Effect of EPL on Programing, Computing Thinking and Problem Solving Ability of Programing Education. The Journal of the Convergence on Culture Technology, 4(4), 287-294.

Webster, C. A., Mindrila, D., Moore, C., Stewart, G., Orendorff, K., \& Taunton, S. (2020). Exploring the role of physical education teachers' domain-specific innovativeness, educational background, and perceived school support in CSPAP adoption. Journal of Teaching in Physical Education, 39(1), 36-47.

Weis, S., Scharf, C., \& Gryl, I. (2017). New and even newer fostering innovativeness in primary education. International E-Journal of Advances in Education, 3(7), 209-219. 